\title{
Investigating Land-Use and Land-Cover Changes of Failaka Island: A Study in Geography and Geoarchaeology
}

\author{
Muhammad G Almatar ${ }^{a}$, Hassan Ashkanani ${ }^{b}$ and Ahmed Hassan ${ }^{c}$
}

${ }^{a}$ GIS and Urban Planning, Department of Geography, College of Social Sciences, Kuwait University, muhammad.almatar@ku.edu.kw

${ }^{\mathbf{b}}$ Anthropological Archaeology, Department of Sociology and Social Work, College of Social Sciences, Kuwait University, hasan.ashkanani@ku.edu.kw

${ }^{\mathbf{c}}$ Ph.D. Geomorphology, Nickname (Ahmed El-kasaby), ORCID: 0000-0001-6157-4284

ameh812000@gmail.com

\section{$\underline{\text { Abstract }}$}

Failaka Island is located 20 kilometers east of the Kuwait mainland. The island includes archaeological sites dating back to the Bronze, Hellenistic, Christian, and Islamic ages. To develop the island as a tourist attraction the state is pursuing a new urban plan based on the island's environmental potential. This study is the basis of the urban plan depends on environmental criteria from the view of Geoarchaeology. The study analysis the land-use and land-cover changes of Failaka Island between 1958- 2018. It provides a topographic survey of the island's coastline and a classification of its geomorphological features and a state of the art identification of its archaeological sites by using a drone to make a terrain model. The study used a medium to high-resolution image analysis of the land-use and land-cover changes: WorldView2-50cm 2010 and 2018; Landsat 8; aerial photography; Drone images and a digital elevation model (DEM), to analysis the expected sea level changes by the end of this century. This study also created a geodatabase of the island that can be adapted for future studies. The results emphasize the importance of preserving the historical and ecological features of the island while developing its infrastructure.

\section{Keywords: Geoarchaeology; Urban Geomorphology; Failaka Island; GIS; RS.}

\section{Introduction.}

Land-use and land-cover changes track the ongoing interaction between humans and their surrounding environment (Cheruto et al., 2016). Land use is the utilization of land by humans that in turn reflects human behaviors, and land cover is the material on the Earth's surface (Mannion, 2002; Rawat \& Kumar, 2015). Human activity impacts the biogeochemical organization that sustains the surrounding biosphere (Meyer \& Turner, 1992). Increased urbanization will lead to the increased loss of vegetation, which may create new environmental problems or magnify existing ones (Rawat \& Kumar, 2015). Therefore, land-use and land-cover change studies are crucial to understanding the environmental and social consequences of urbanization and for identifying the temporal and spatial changes to the Earth's surface (Cheruto et al., 2016).

Remote-sensing and geographic information systems (GIS) are powerful tools to investigate land-use and land-cover changes, as the comparative analysis of remote sensing images from different time periods can accurately identify these changes (Mukhtar, 2016). Many studies have utilized remote sensing to track land-cover changes such as afforestation, deforestation, and the loss of agricultural land (Rawat \& Kumar, 2015; Mukhtar, 2016). Because most of the research from the last two decades focused on the importance of vegetation as a land cover, few studies have used remote 
sensing to investigate urban and archaeological areas (Fragkias \& Seto, 2007). Identifying land-use and land-cover changes in these areas may minimize unplanned expansions and discourage other land uses that can create serious environmental and social problems (Rawat \& Kumar, 2015).

Because of the viability of remote sensing and GIS in many geoarchaeological studies, these technologies have proven crucial to advancing the field (Themistocleous et al., 2015). Remote sensing has been used in several archaeological studies to analyze geological settings, conduct surveys, and assist prospection (Deroin et al., 2012). Notably, remote sensing can identify traces of human activity and buried remains (Themistocleous et al., 2015). Geoarchaeologists have utilized remote sensing and GIS to map known historical sites and to identify undiscovered historical sites (Breeze et al., 2015). In addition, they have analyzed satellite images to determine the locations of archaeological deposits, which can be categorized by their historical and cultural periods. The utility of remote sensing for this purpose depends on the size of the studied area and the availability of high-resolution images. High-resolution images are viable data sources for creating geoarchaeological databases, and they also minimize the cost of data collection (Keay et al., 2014).

A land-use perspective was applied to study the sociopolitical and economic complexity of Kuwait's Ubaid period. The Ubaid period is a late Neolithic period (LNP) that began in the sixth millennium B.C. In Al Subbiya, north of Kuwait Bay, an over 7000-year-old settlement of this period was excavated. A chemical analysis of the Ubaid pottery revealed that the bitumen coated inside was obtained from Burgan in southern Kuwait (Carter \& Crawford, 2003), and this result suggests that small-scale trade routes were present within the Kuwait region during this period. Instead of focusing on the long-distance trade routes between different Gulf entities and Mesopotamia, the study used the Burgan bitumen to clarify the small-scale interactions between Subbyia settlers and their movements within the region, which demonstrates how localized land use is affected by ideological, economic, and social factors.

The land use of Failaka Island during the Bronze Age has been assessed by tracking the different clay sources used to make pottery there. Ashkanani (2016) collected hundreds of ceramic potsherds from different Bronze Age archaeological sites on Failaka to investigate the movement of the Failakan settlers and their acquisition of raw materials during the second millennium B.C. Using portable X-ray fluorescence and microscopic thin-section analyses, the study demonstrated that specific clay sources were used consistently and with limited changes over thousands of years. However, according to a petrographic analysis, five samples from the Dilmun site contained clay embedded with volcanic and metamorphic rock fragments. The volcanic components had the high salt contents found in the clay and sand of Subbyia, which is part of the Dibdibba formation. This result indicates that the Failakan settlers were not limited to utilizing only Failakan or Bahraini clay sources during the Bronze Age, and their movements likely extended over the land of Kuwait.

The present study utilized remote sensing and GIS to identify the land-use and land-cover changes to Failaka Island. Because the island has the richest historical sites in the country, its preservation is of great cultural importance. This geospatial and geoarchaeological study has generated several layers for Failaka Island, and it will help developers, decision-makers, and urban planners to understand the land-use and land-cover distribution of the island. This study used fieldwork to complete its coastline classification and site investigations.

\section{Study Area.}

Failaka Island is located 20 kilometers off of the Kuwait coast between $29^{\circ} 23$ and $29^{\circ} 28^{\prime} 16$ North and $48^{\circ} 16$ and $48^{\circ} 24^{\prime} 10$ East (Fig.1). The island is approximately 13.8 kilometers long and 1.8 to 6.5 kilometers wide, and its area is approximately 44 square kilometers, with its base in the west 
and its head in the southeast. The island is flat, apart from a small hill approximately 9 meters high on its western side. Geologically, Failaka Island is a structural extension of the Jal Al-Zour, an extended bank of the Khor Subbyia formed by sand and chalky-lime sandstone from the Neogene period with secondary pebbles (Dalongeville, 1990; Patitucci \& Uggeri, 1984).

The island's climate is hot and arid with moderate winds. The temperature reaches a maximum of $50^{\circ} \mathrm{C}$ in summer and a minimum of $4{ }^{\circ} \mathrm{C}$ in winter. The average monthly wind speeds on the island range from $3 \cdot 3-7 \cdot 3 \mathrm{~m} / \mathrm{s}$. The approximate annual rainfall is $130 \mathrm{~mm}$ (Al-Sarawi et al, 1996). Failaka Island is linked by ferries to two man-made harbors and by a submarine fresh water pipeline to Kuwait City. Although the island has its own source of water, it is insufficient for the population because of the growth prior to the Iraqi Invasion. Three submarine power cables, which are parallel to the pipeline, provide electricity (Al-Zaher \& Aziz, 2004).

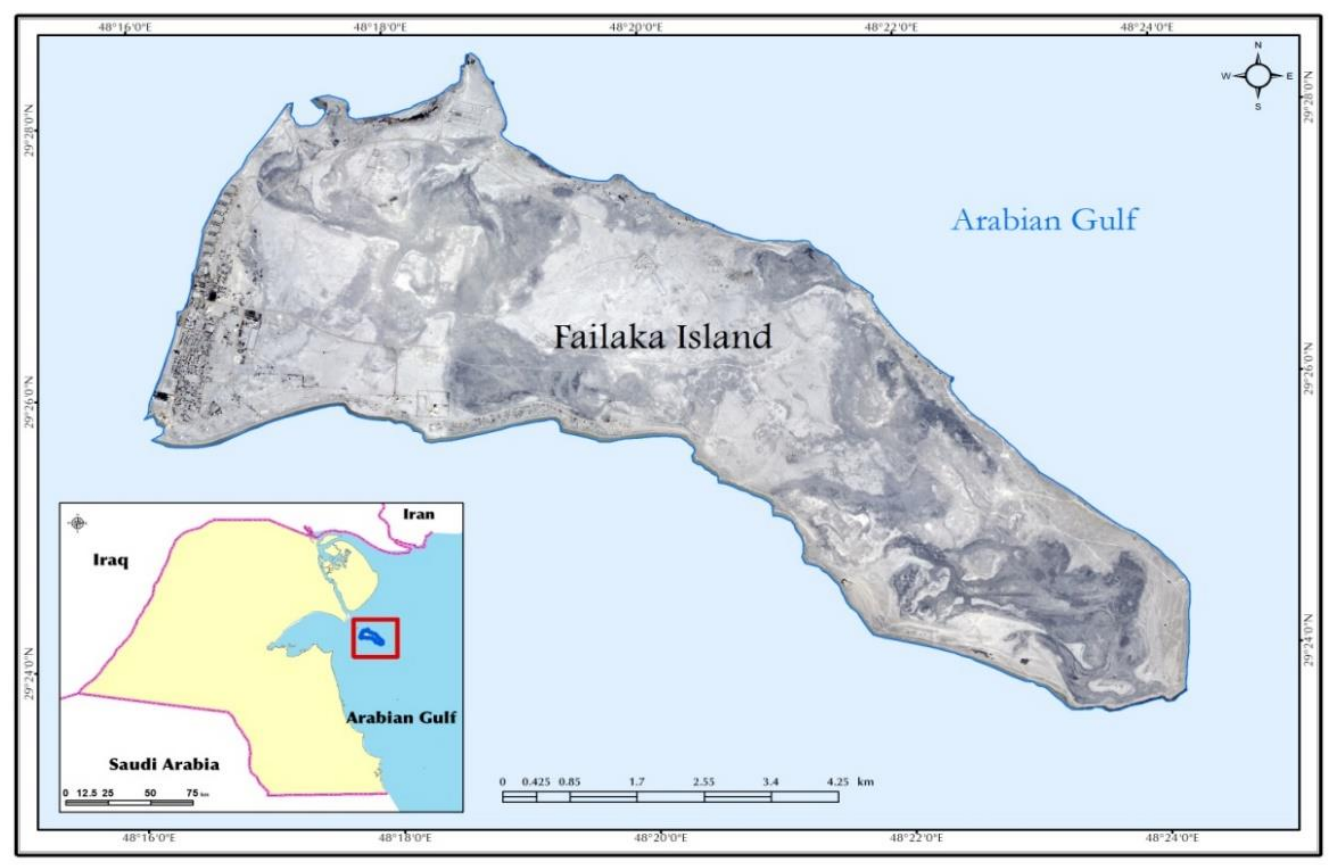

Fig 1. The location of Failaka Island, Source: (WorldView-2-50cm, 2018)

Objectives: The study has four objectives:

- To survey Failaka Island's coastline and gather geomorphological data for classification of coastline types.

- To identify and update archaeological sites using unmanned aircraft and terrain modeling.

- To monitor land-use and land-cover changes by analyzing medium- and high-resolution images (WorldView2-50cm-2010 and 2018; Google earth 2018; Drone image Mavic2 pro; aerial photography, 2004 and an historic map from 1958).

- To predict the sea-level changes by the end of this century with a digital elevation model (DEM). 


\section{Literature Review.}

Failaka Island has been the subject of a wide range of previous studies. Salem focused on its historical and geographical aspects, such as in his article (1977) on its development, his study (1980) on historical and social aspects, his historical map (1997), and his book (2006). Mostafa's book (1988) covered its location, geography, population, economic activity, and future. Al-Sarawi et al. (1996) studied Failaka Island's morphological map, coastal hydrodynamics, and coastal zone management. However, this morphological map did not classify the beaches and simplified the challenges of urban planning. Al-zaher and Aziz (2004) completed an applied study of the island that used remote sensing and GIS, and it compared satellite images with old maps. However, the urban plan proposed by this study has a high implementation cost, and it was not based on a coastline classification depending on the fieldwork. Furthermore, this plan did not take into account the island's rich archaeological sites.

The Kuwaiti-Slovak Joint Archaeological Mission (KSAM) has conducted several geophysical mapping studies at the Al-Khidr site, dated to the Bronze Age, and the Al-Qusur site, dated to the Islamic/Christian age. These studies utilized ground-penetrating radar (GPR) to analyze the courtyard houses and storage rooms on Failaka Island. Dipole electromagnetic profiling (DEMP), GPR, and magnetic methods were applied at the Al-Khidr site to identify its archaeological structures and estimate its total size. The results show that these geoarchaeological methods can detect cemetery grounds, architectural remains, and horizontal and vertical components (Barta et al., 2007). Pieta et al. (2009) used the GPR mapping technique and archaeological excavations to form a general plan of the Al-Qusur settlement. The results are supported by the details of known settlement units, such as farmsteads and courtyard houses, and other isolated structures.

\section{Methodology.}

This study used remote sensing softwares and ArcGIS to layout the land-use and land-cover changes to Failaka Island from 1958 to 2018. ArcGIS 10.4 desktop was used along with ERDAS Imagine 2014 to classify the satellite image (Landsat 8- 2018, WorldView2-50cm-2010 and 2018, aerial photography 2018, taken by drone Mavic2 pro). Satellite image processing has gone through the following steps: 1- Registered and classified using unsupervised classification. 2- A change detection technique determined the land-use and land-cover changes to the study area. 3- After defining these changes, a new geodatabase was created to record the changes and the island's historical and urban sites. 4- Obtain results and measurements.

The sea level prediction map was created from, the Global Sea Level Rise Map by Alex Tingle (http://flood.firetree.net). This estimates the degree of inundation, which was compared to the hazard map, produced from DEM from the Municipality of Kuwait. The study also used unmanned aerial vehicles (UAV) to identify archaeological sites with terrain modeling, a new technique for modeling the Earth's surface. Using UAV for feature identification has gained traction in urban-planning, landuse, and geomorphological studies. The technology provided high-resolution imageries of the archeological sites. To acquire usable data, extensive fieldwork was required. Fieldwork can correct errors in maps and satellite images. In addition, it allows for site investigation, sample collection, and the observation of geomorphological phenomena. In particular, sample collection is crucial to remote sensing and GIS research. The normalized difference vegetation index (NDVI) analyses of the Landsat images from 1992 and 2018 to determine the changes to vegetation in the study area, because of its many connotations of environmental and geomorphological changes. 


\section{5. $\underline{\text { Results. }}$}

\subsection{The Topographical and Geological Characteristics of Failaka Island.}

Failaka Island has a simple terrain and spacious plains with a few rises. It consists of flat sabkhas and sandy sheets vegetated with small plants. The sand gathered around these plants can form Nabkhas, located in the central and southwestern regions of the island, the highest elevations are roughly 9.3 meters above the mean sea level (Fig 2 and 3). Most of the island is under the 5-meter contour line. One of the most important facilities on the coast is the 472-unit holiday resort on the southern side and this area has been deserted since the Iraqi invasion until now, as has the entire island.

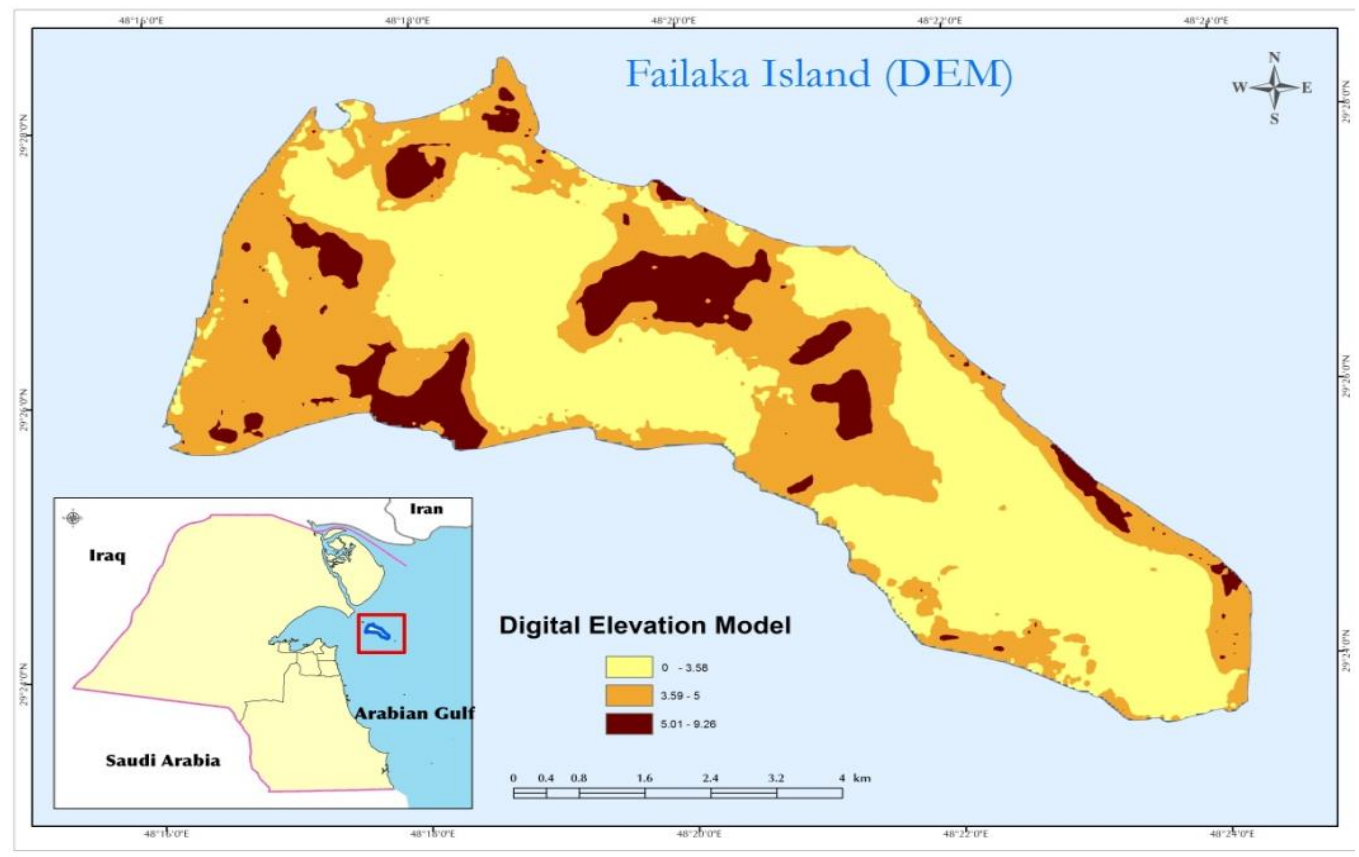

Fig 2. Digital elevation Model of Failaka Island

Source: Aerial photography, 2004, Kuwait Municipality, 25 cm. 


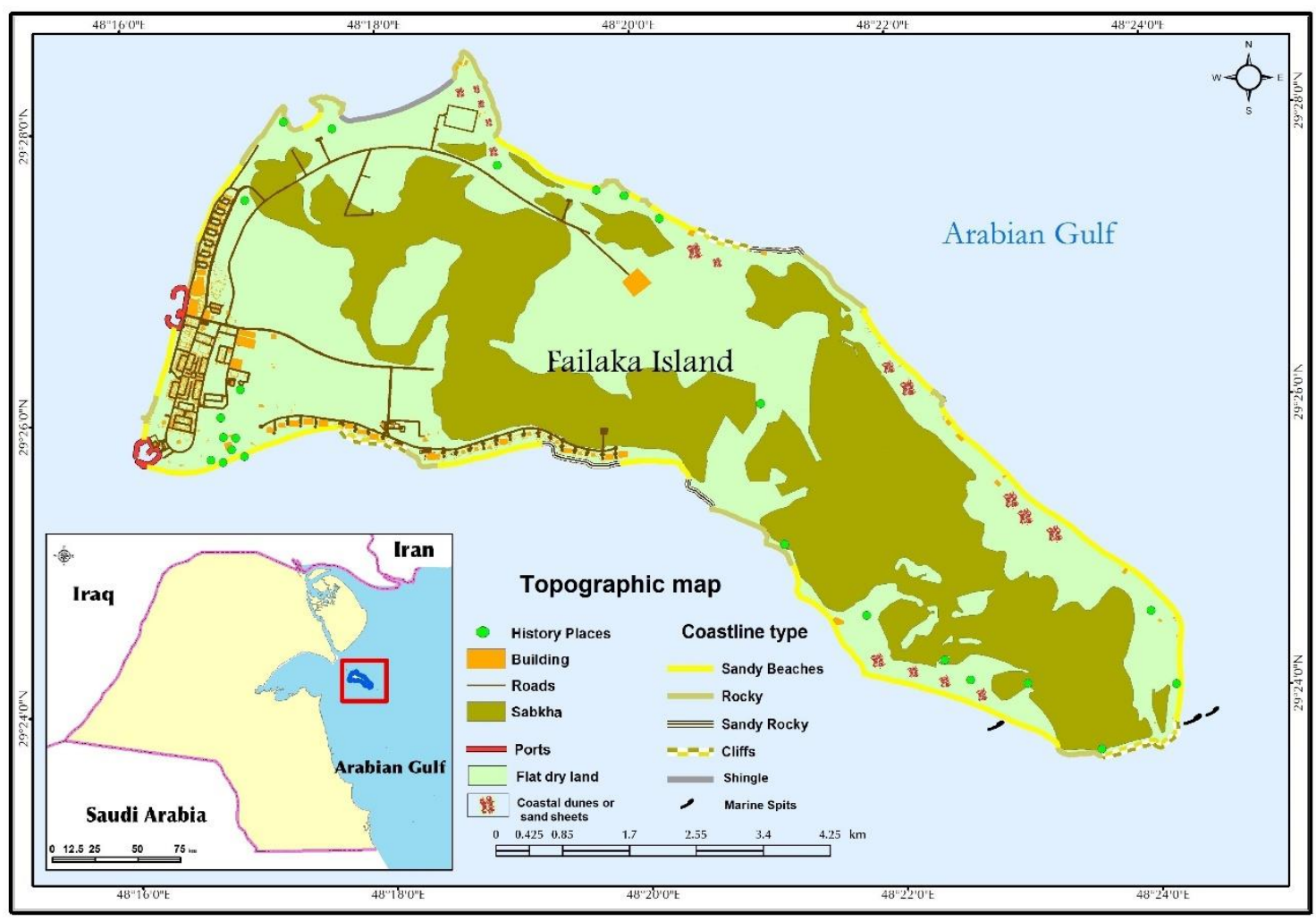

Fig 3. Topographic map of Failaka Island, source (Field study; Worldview2-50cm-2018; Google earth 2018; and drone image Mavic2 pro).

Geological formations are simple on Failaka Island as in (Fig 4). The most important of these falls into four categories:

Cemented coastal deposits or Oolitic complexes. An Oolitic complex is a series of ridges that is part marine and part aeolian. These ridges formed alongside the barrier beaches and coastal dunes, which are separated from the Gulf by coastal lagoons and sabkhas and were deposited during high water stands. They consist of oolitic sand, sandstone, and limestone.

Dibdibah formations. These formations belong to the Pleistocene era and appear as coarse-grained, pebbly sand with a thin intercalation of clayey sand and clay. These sediments are sometimes combined with calcium carbonate and gypsum to produce conglomerates.

Sabkha deposits. Most geomorphological units are widespread on the island, and their surface levels vary between 0 and 3 meters, which are extremely flat and usually barren of any vegetation Fig. 5 (Picha \& Saleh, 1977). This type of sediment is usually under the constant influence of saline groundwater and susceptible to floods at certain times. The Sabkha deposits area is roughly $20.1 \mathrm{~km}^{2}$, and this area constitutes $45.7 \%$ of the total area of the island (WorldView2 $-50 \mathrm{~cm}, 2018$ ).

Strand line deposits. These shell-sand and shingle sites appear on the coast in the form of beach gravel and minor unconsolidated beach sand. 


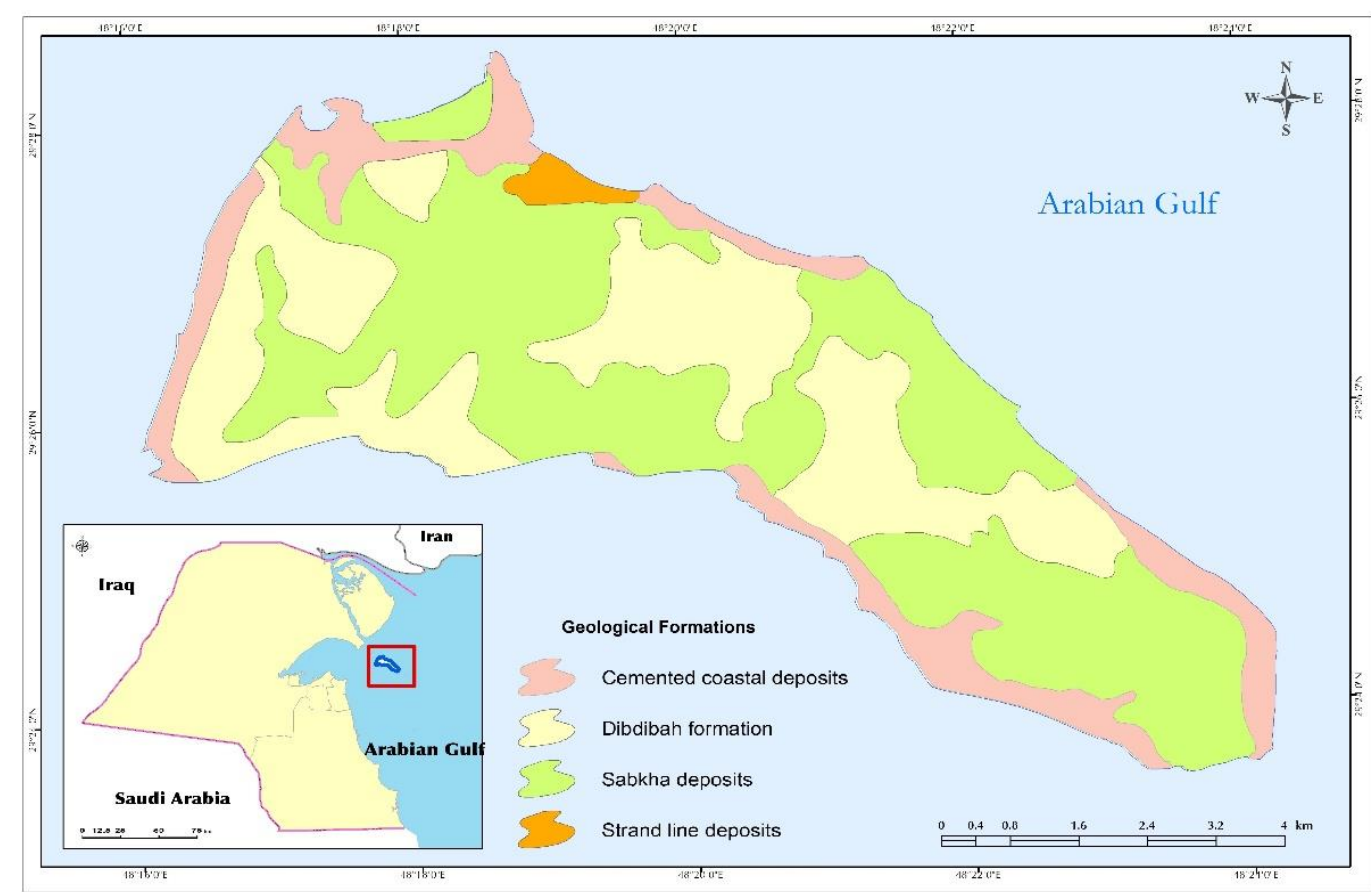

Fig 4. Geological map of Failaka Island, Source (KOC, 1985).

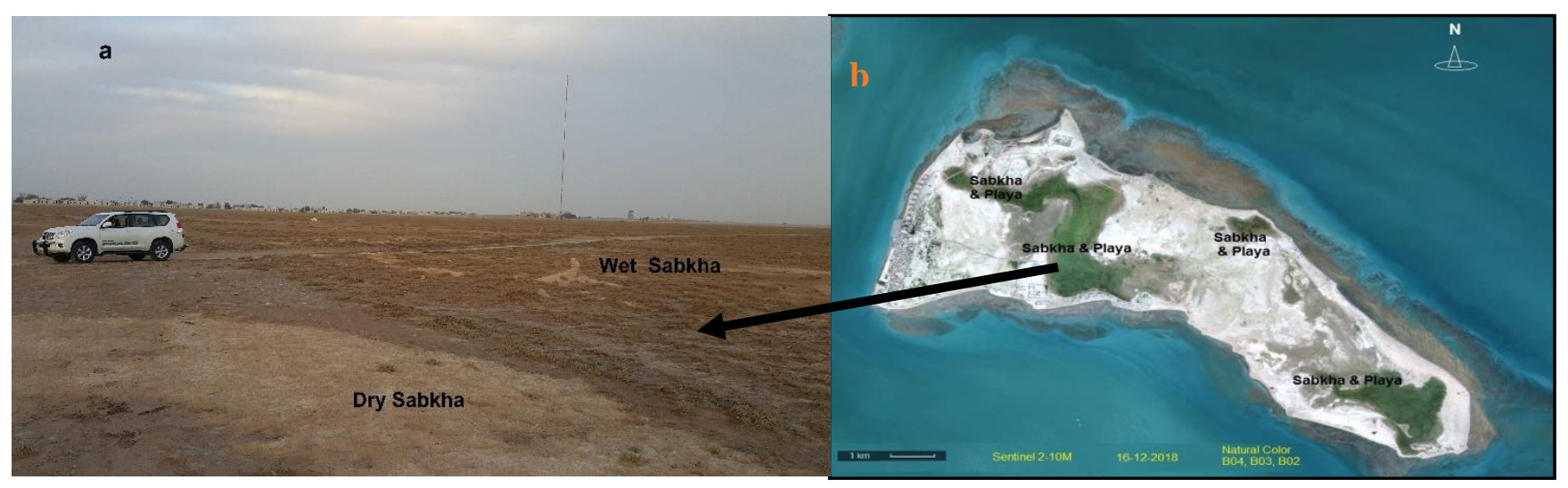

Fig 5. a) Sabkha deposits in the southwest of Failaka Island. b) The sabkhas filled with water after the rainy season, Source: Satellite imagery, Sentinel 2-10M- Natural Color, 16 Dec 2018.

\subsection{Coastal geomorphology.}

The coastal phenomena of the island can be classified into those caused by marine erosion and those caused by marine deposition. The most important examples of the marine erosion category are the marine cliffs, shore platforms, headlands, and bays (Fig. 6). The most important examples of 
marine deposition are the beaches, beach cusps, spits, tidal flats, coastal sabkhas, and coastal sand dunes. The coastal zone is affected by both natural and human activities. In nature, tides and waves are two of the major contributors to coastal processes. The impact of humans is small here because the island was deserted from 1990, and the impact is limited to visitors land and beaches in small numbers, so it can be said that the most appropriate place to see the geomorphological phenomena of marine erosion and marine deposition on the coast of Kuwait is Failaka Island. The length of the Failaka coastline is $38.75 \mathrm{~km}$. Based on field study, analysis of the satellite images and drone images (UAV photogrammetry ${ }^{1}$ ), and the photographs, the coastline can be classified into six types (Fig. 7 and table 1).

Sandy beaches. With a total length of 21.35 kilometers, the sandy beaches constitute $55 \%$ of the coastline. These beaches are common in the sector of the East Alqurainiyah and Alsubahiya on the southern coast of the island. Based on the fieldwork and the geological map, the sandy beaches are characterized by calcareous sand stone, with an increase in the sedimentation of the oolitic sandstone deposits. This is what gives these beaches their light color as in fig 8. Sandy beaches in Failaka are not steep, and their gradient varies between $7^{\circ}$ and $10^{\circ}$.

Table 1. Lengths of beach types on Failaka Island

\begin{tabular}{|l|l|l|}
\hline \multicolumn{1}{|c|}{ Type } & \multicolumn{1}{c|}{ Length $(\mathbf{k m})$} & \multicolumn{1}{c|}{ \% } \\
\hline Sandy beaches & 21.35 & 55.08 \\
\hline Rocky beaches & 9.6 & 24.76 \\
\hline Shingle beaches & 1.62 & 4.18 \\
\hline Sandy, rocky beaches & 2.3 & 5.96 \\
\hline Cliffs & 2.7 & 6.97 \\
\hline Ports & 1.18 & 3.05 \\
\hline Total & 38.75 & 100 \\
\hline
\end{tabular}

Source: (Field study; drone image Mavic2 pro; WorldView2-50cm-2018; and Google earth 2018).

1) To make a topographic survey of the coastline using a drone, the study relied on the following steps: 1- Dividing the coastline of sectors representing all the geomorphological phenomena on the island. 2- Making aerial photography for the coastline as in the forms 6, 8 and 13. 3-Mosaic preparation of images through drone image software such as Pixd4D or Drone2map. 4- Layouts and geomorphological analysis. As has been done in many recent studies around the world (Goncalves and Henriques, 2015; Yoo and Oh, 2016). 

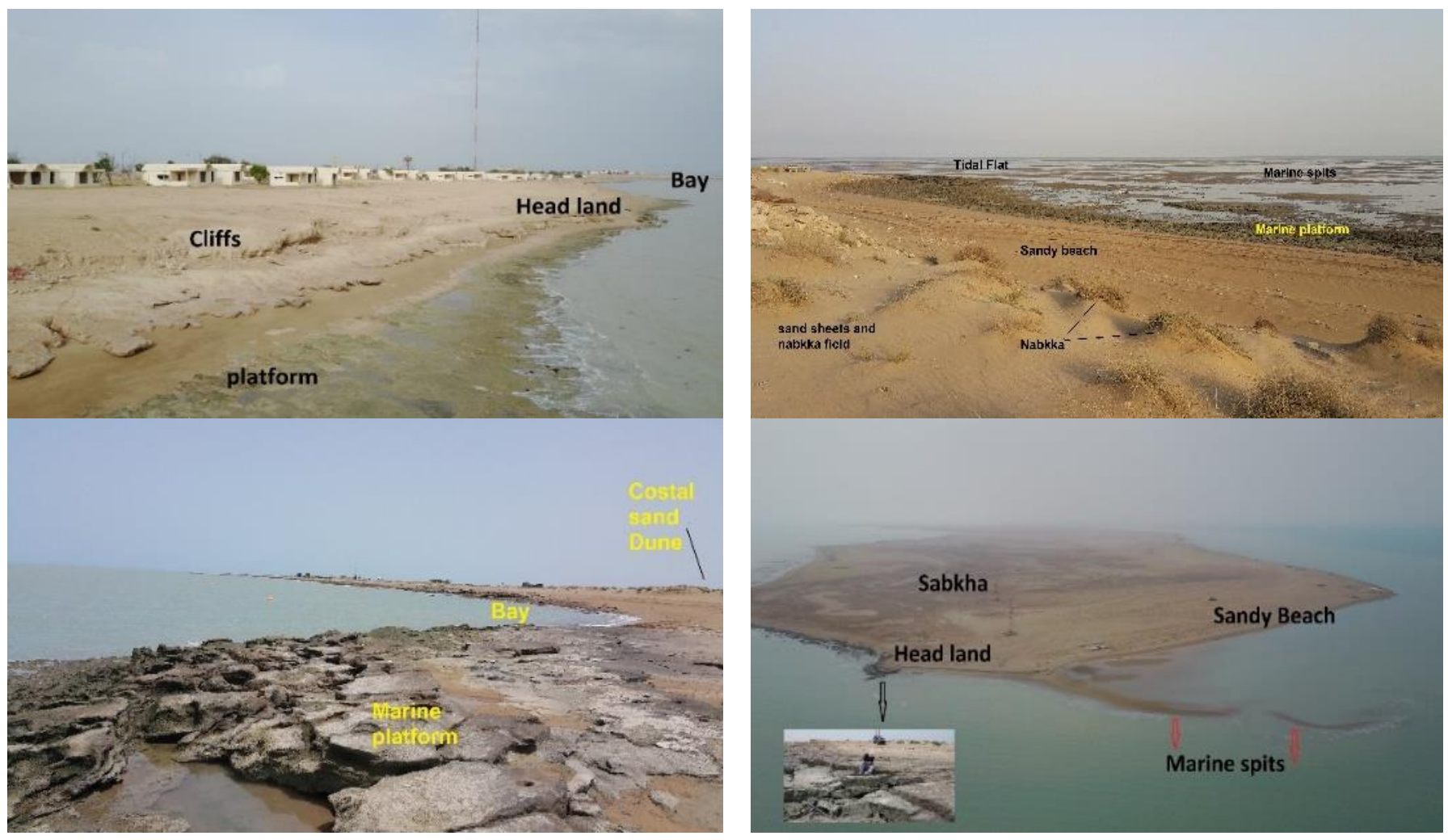

Fig 6. Some geomorphological landforms on the coastline of Failaka Island.

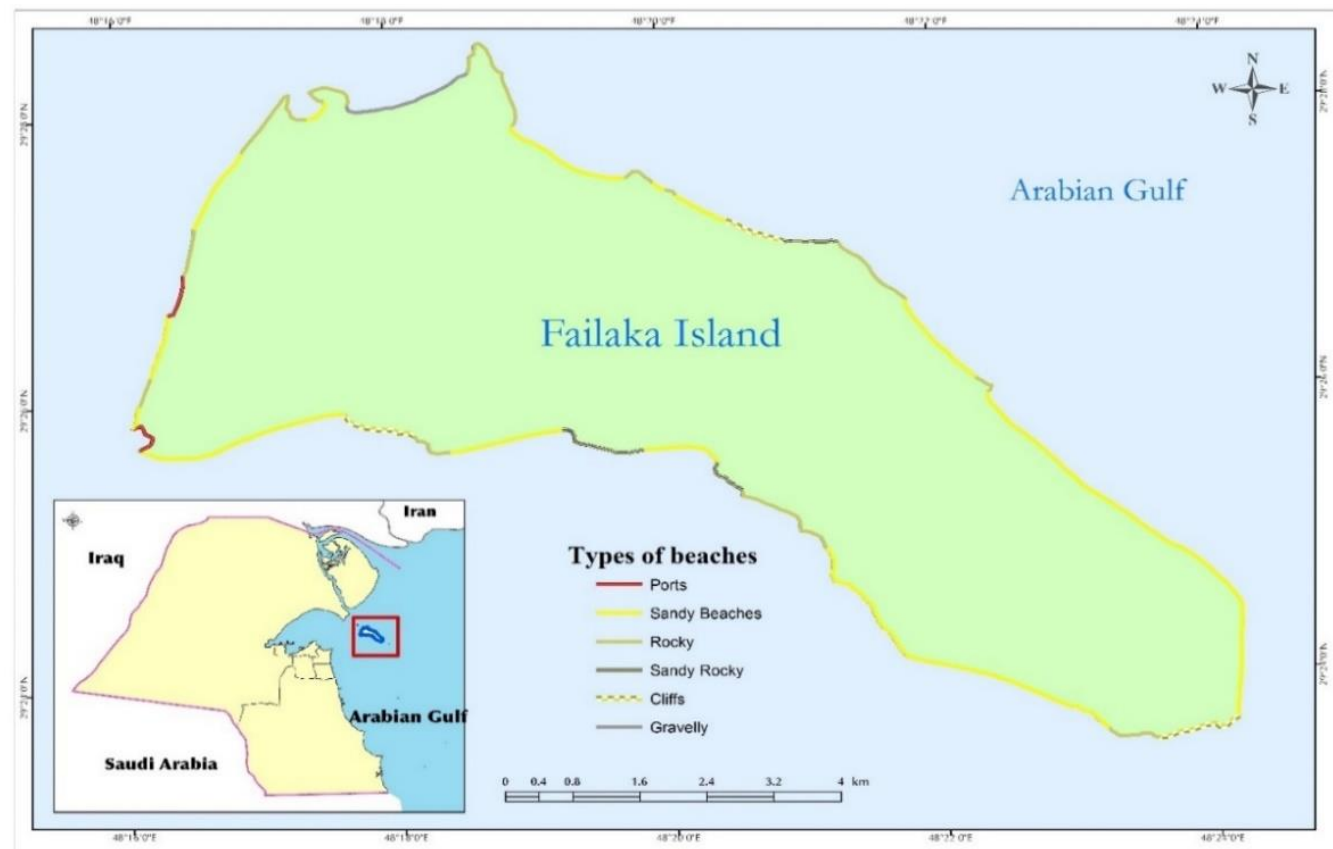

Fig 7. The types of beaches on Failaka Island. Source: (Field study; drone image Mavic2 pro; WorldView2-50cm-2018; and Google earth 2018). 


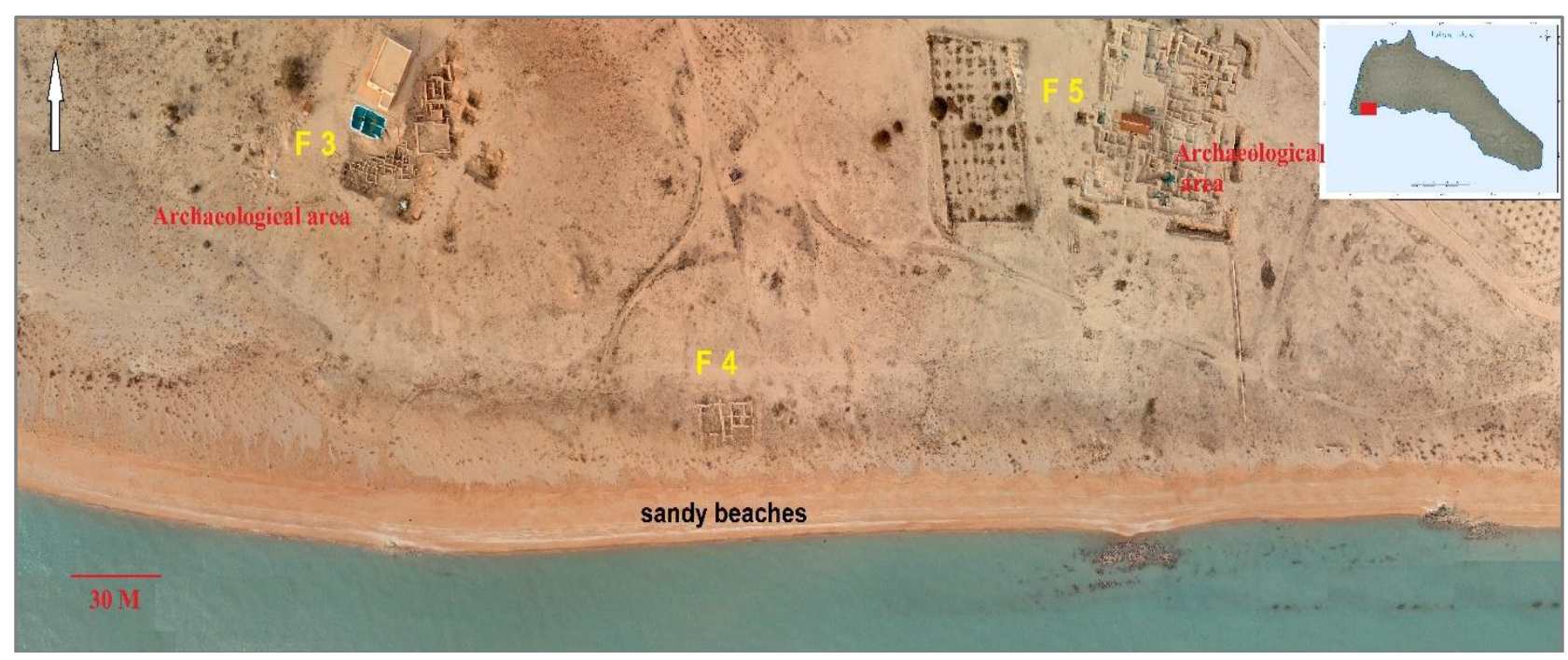

Fig 8. Mosaic 2D modeling of the sandy beach and archaeological area in the southwest of Failaka Island, formed from 127 UAV photographs at an altitude of 66 meters. Source: (Field survey by drone Mavic2 pro and Pix4Dmapper)

Rocky beaches. With a total length of 9.6 kilometers, the rocky beaches constitute $24.7 \%$ of the coastline. The rocky beaches are found at Al-Khidr and Shobiga. These beaches formed as sandstone mixed with shells and a fine material that gave it stiffness turned into a conglomerate. The rocky beaches in Failaka Island are characterized by solution weathering, which appear in the form of several geomorphological phenomena resulting from Wetting and Drying Weathering.

Shingle beaches. With a total length of 1.62 kilometers, the shingle beaches constitute $4.18 \%$ of the coastline (Fig. 10). They can be found at the Aldasht ruins and Alsubahiya, The sediment consists of sand and a mixture of shell fragments with median diameters ranging from $0.4-1.5 \mathrm{~mm}$ (AlSarawi et al., 1996).
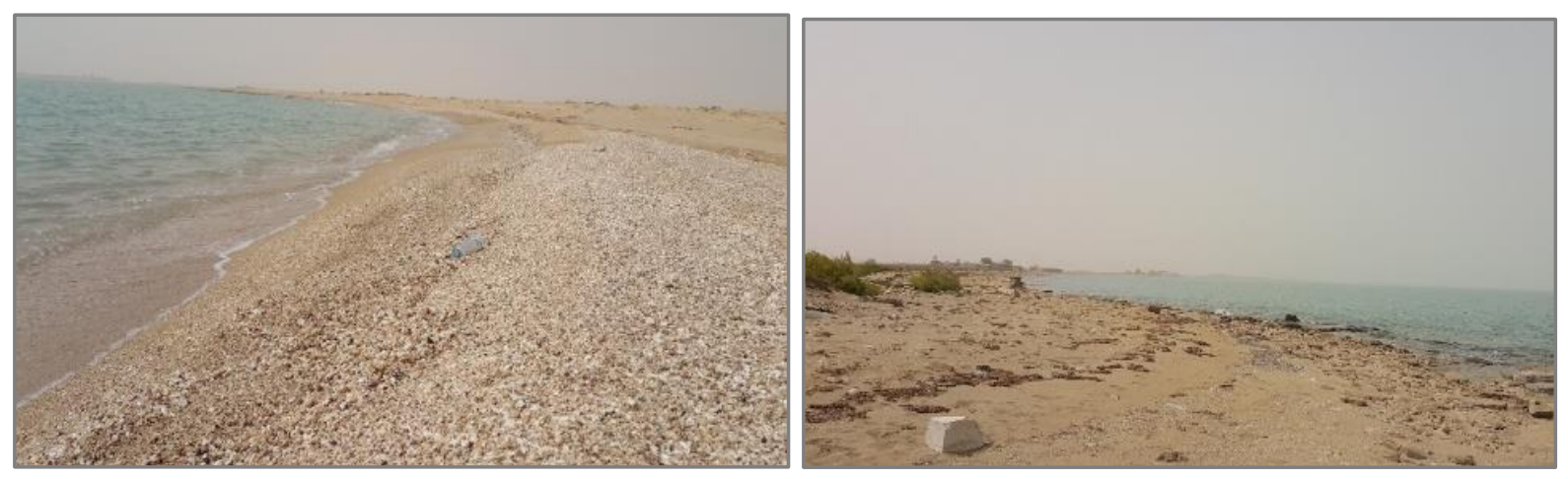

Fig 9. The shingle beaches of Failaka Island.

Sandy, rocky beaches. With a total length of 2.3 kilometers, the sandy, rocky beaches constitute $5.96 \%$ of the coastline. They are located on the northern coast. The slope in rocky beaches in Failaka ranges between $30^{\circ}-45^{\circ}$ and $90^{\circ}$ in a few areas in Shobiga. 
Cliffs. With a total length of 2.7 kilometers, the cliffs constitute $6.97 \%$ of the coastline. The marine cliffs are located at three locations on the island: the middle of the northern coast, the far east, and the southwest. The heights of cliffs are different: 3 meters, 2 meters, and 8 meters respectively. These cliffs feature multi-directional faults and joints and false bedding (Fig. 10).
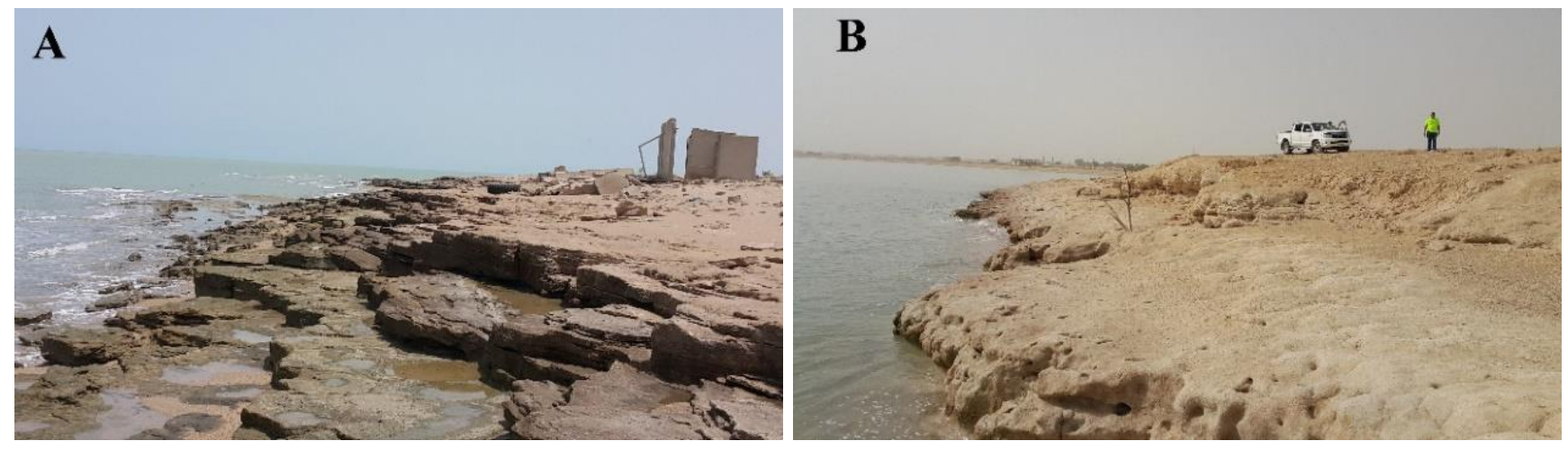

Fig 10. The cliffs of Failaka Island, A) east of Alqurainiyah in the middle of the north coast. B) At Shobiga in the southwest coast.

Ports. With a total length of 1.18 kilometers, the ports constitute $3 \%$ of the coastline. Both ports are located in the west. The port at the far southwest of the island is a simple and uninhabited harbor in the case of a low tide.

\subsection{Identification of Archaeological Sites Using UAV.}

The archaeological sites on Failaka Island extend along the shoreline as well as through the middle of the island (fig. 11). Most archaeological missions have focused on the southwestern and northwestern parts of the island. Archaeological records support the island's occupation from the late Islamic to the modern era. The Danish mission has been operating since 1958, making it the first archaeological excavation in the history of Kuwait. There are several archaeological sites that have not been studied, such as: Dasht, Al-Sabahiyah, Al-Sa'id, Al-Ali, Al-Awazim, and Matitah, which have only been surveyed. The following are the most important archaeological sites on the island.

Al-Khidr is a Bronze Age site, known as the Dilmun-Culture port, located in the northwest of Failaka Island. It was fully excavated in 2004 by KSAM. The survey indicated the presence of numerous sherds, stone structures, metal objects, fauna and flora remains, pearl and fishing hooks, and over 600 Dilmun stamps seals. The site is below a modern Islamic cemetery that stretches along the western shore of the shallow Al-Khidr bay, which served as a port in the past (Benedikova \& Barta, 2009). Today, the Al-Khidr site consists of three visible mounds and two less visible mounds. 
The KH-1 mound is a low mound roughly 3 to 3.5 meters above the contemporary seabed of Al-Khidr bay and stretches 150 meters in a north-south direction. It is a sandy dune with shrubby vegetation. Due to high tides, water erosion (2-4 meters) has damaged the growth of this vegetation (Benedikova \& Barta, 2009).

The F3 mound is a Bronze Age mound referenced by the Danish mission in 1958, and the islanders know it as Tell Sa'ad. It is roughly 2.90 meters above sea level. It contains a residential settlement with domestic activities, including archaeological evidence of an elite or temple-like structure, the skeletons of gazelles and goats, 170 round stamp seals, and some kilns for an unknown purpose (Ashkanani, 2016). On the top of this mound, the summerhouse of Ahmad Al-Jaber AlSabah, the sheikh of Kuwait, was built during the 1920s (Ashkanani, 2018).

The F5 mound is an Iron age mound that represents the Seleucid culture, post-Alexander the Great, and it is also known as Tell Sa'id. The site was a subject of the first archaeological mission by the Danes (fig. 13). It is now understood to be a Hellenistic fortress that consists of multiple residential units, two temples, multiple storage areas, two gates, and a trench. The French archaeological mission has been working on the site since the 1980s (Ashkanani, 2016).

The F6 mound is a Bronze age mound located near Tell Sa'ad and Tell Sa'id, and it is also known as the palace. It is the oldest archaeological site on the island that is associated with the third Ur dynasty and the Dilmun occupation, dated around 2200 B.C. The site consists of a palace-like structure and a Dilmun temple at 4.20 meters above sea level (Ashkanani, 2016).

Al-Qusur is situated in the middle of the island with elevations ranging from roughly 5 meters to 2 meters above sea level. Surrounded by marshes, it is the largest archaeological site on Failaka Island, and it covers roughly 2 by 2.6 kilometers with archaeological remains (Pieta at el., 2009). Over one hundred structures have been found by Italian, Slovakian, and French missions, such as the foundations of courtyard houses, church buildings, a central building, and an oval structure. The archaeological records support the presence of a Christian community and a monarchy from the 7 th to 9 th century A.D.

The Al-Quraniya mound is located in the west-central part of Failaka Island along the north shore, and it is roughly 550 meters long and 250 meters wide. With an elevation of roughly 6-8 meters above sea level, Al-Quranyia is one of the highest architectural sites on the island, and it contains an old village with 30 structures, mixed grasses and shrubs, and a deserted modern farm (Shehab et al., 2009). The old village dates back to roughly 200-4400 years ago, according to the features of the Arabic corner tower, the square courtyard with buildings, the plain and incised pottery, and the glazed ware. 


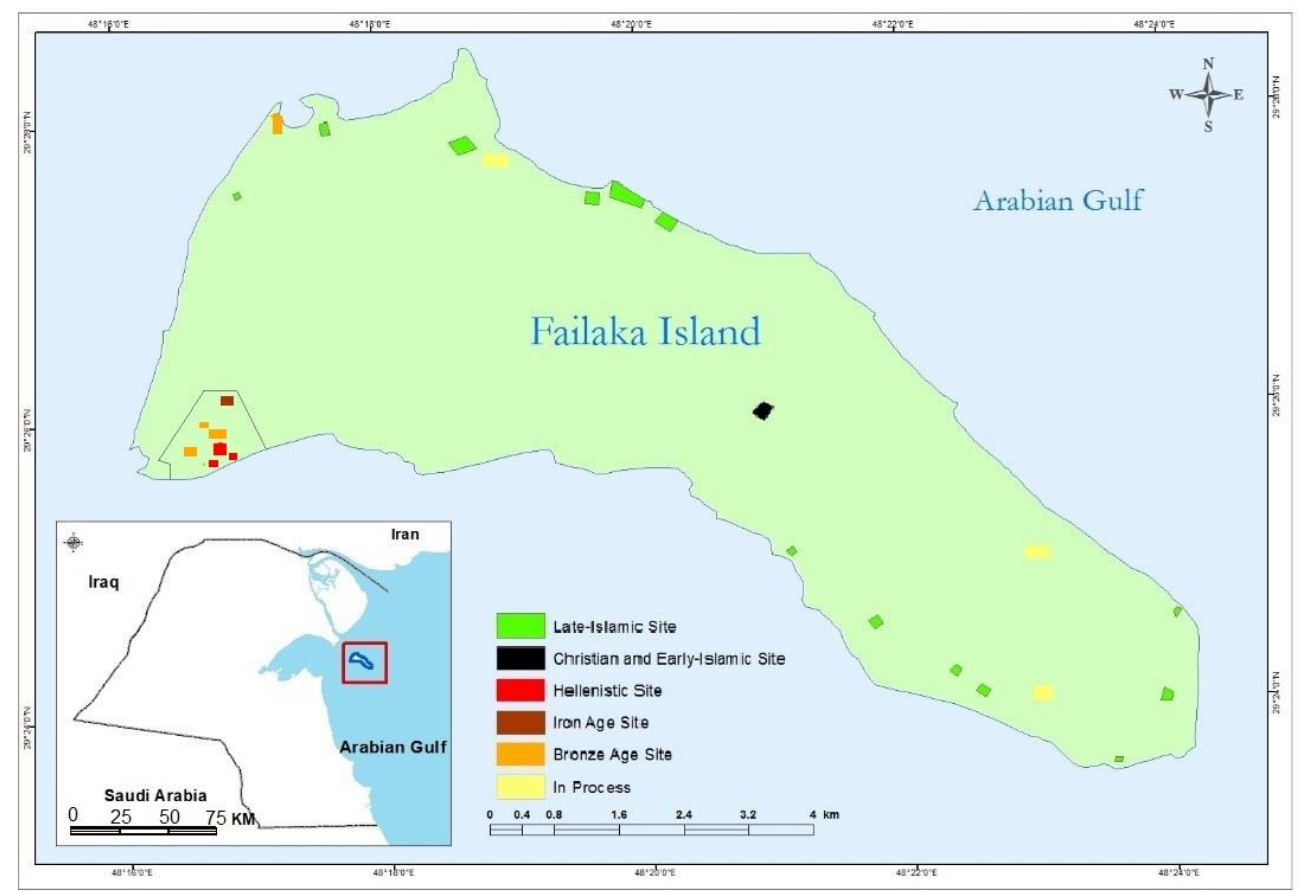

Fig 11. The archaeological sites on Failaka Island. Sources: (Drones Mavic2 Pro and Phantom 4; field study and worldView2-50 cm 2010 - 2018).

In recent years, UAV have become a common tool to study archaeological sites, select the most suitable places for digging, and identify new sites. (Jesse Casana et al., 2017) ${ }^{2}$. Due to differences in composition, density, and moisture content, materials on and below the ground surface absorb, emit, transmit, and reflect thermal infrared radiation at different rates, as well as the moisture content of the soil, evaporation processes and the form of salt polygons. These vary according to the rock components and ancient archaeological buildings buried under the surface as in figs. 12 and 13. The most suitable sites for drilling based on these geomorphological criteria can be determined, even if thermal imaging is available (fig, 12), which will be an important factor in determining the most suitable areas for drilling.

2) This paper offers archaeologists interested in aerial thermography a straightforward guide to the basic principles, suitable technology options, and key survey strategies, highlighting results from several different archaeological sites. 


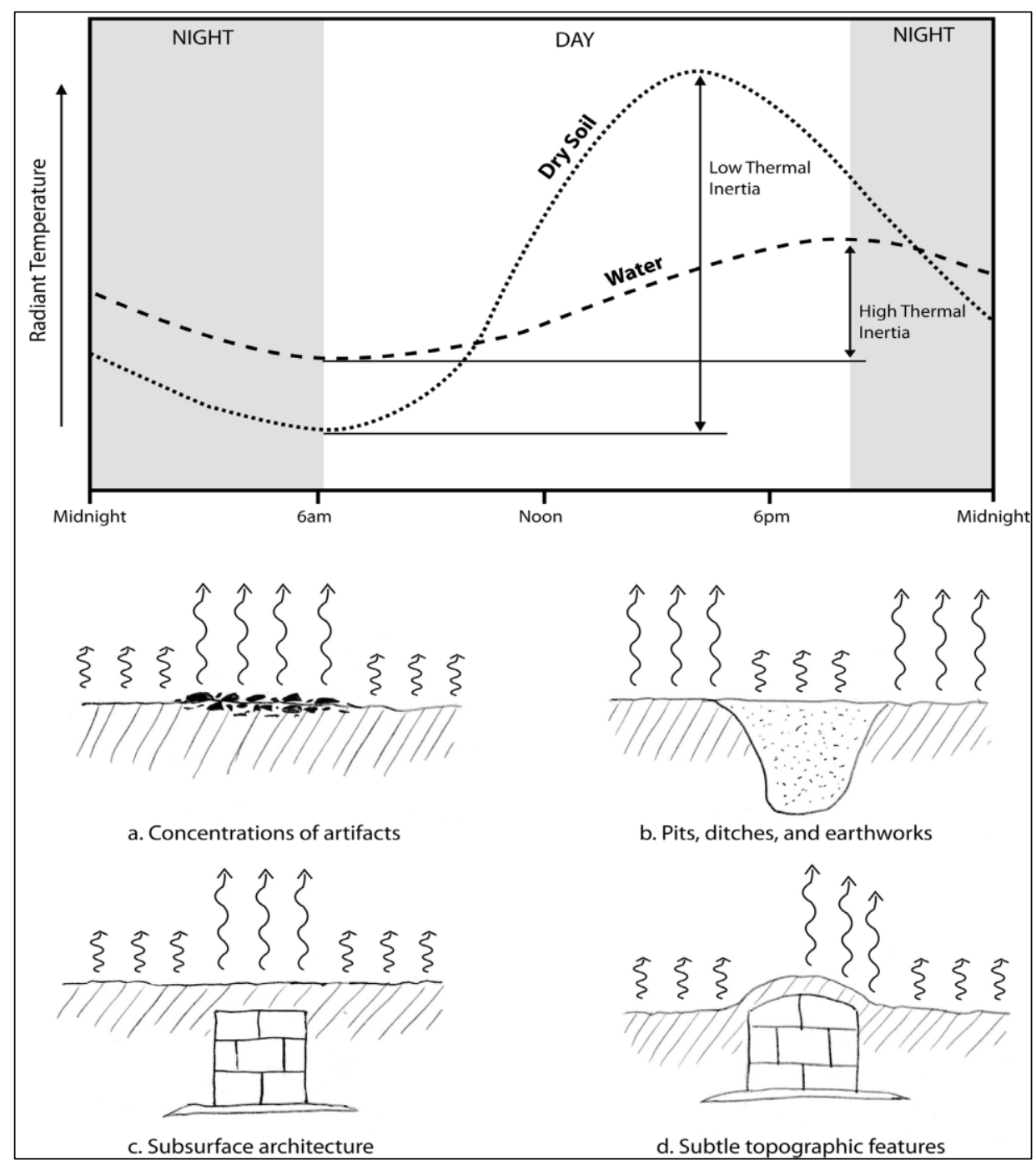

Fig 12. A hypothetical illustration of the relative thermal radiance of dry rocks and soil versus water or saturated soil over a diurnal cycle (after: Kuenzer and Dech 2013). Due to these differences, wide ranges of archaeological features are potentially resolvable in thermal imagery, (after: Jesse Casana et al., 2017). 


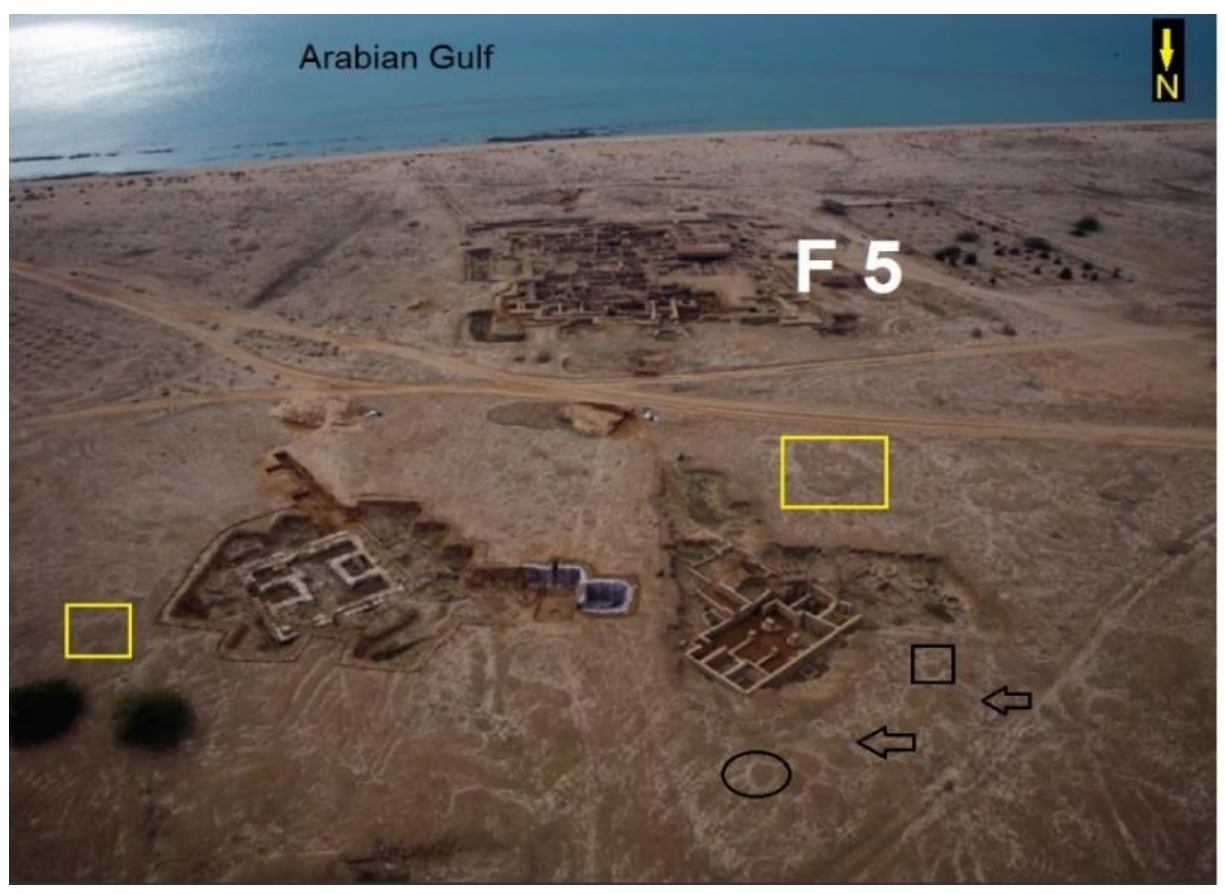

Fig 13. An oblique photography for F5 mound, in the southwest of the island, illustrates saline polygons and evaporation processes that take geomorphological forms that can guide the excavation of archaeological sites in Failaka, taken by drone Mavic2 pro, altitude 40 M, before sunset, March 31-2018.

\subsection{The Land-Use and Land-Cover Changes.}

To assess the land-use and land-cover changes, the study generated geodatabases of the island's urban distributions for the years 1958, 2004, 2010, and 2018 (Fig. 14). The historical map for the year 1958 was obtained from the Center for Research and Studies on Kuwait (Salem, 1997). The 2004 geodatabase was generated from aerial photography taken of the island (Kuwait Municipality, 2004). The 2010 and 2018 geodatabase utilized images from the WorldView2-50cm. The UAV images were used for site investigations of the remote-sensing images and field study.

The results demonstrate that urban land use and beach type are related. Urban land use mainly took place in the western, eastern, and southwestern areas of the island. The urban areas were generated near the sandy beaches. The western area of the island was chosen as the site for a port, as it had the appropriate water depth, distance to the mainland, and beach types (sandy and sandy, rocky beaches). Urban land use increased around the port area, which explains the notable urban development to the west. The urban development in the east and southwest is related to the presence of sandy and sandy, rocky beaches, as other beaches are not suitable for this purpose. 
Table 2. The urban growth stages of Failaka Island (1958-2018).

\begin{tabular}{|c|c|c|c|c|}
\hline Years & Non-Urban & Urban & Area $\left(\mathbf{m}^{2}\right)$ & Urban \% \\
\hline 1958 & 44502397.12 & 1928323.71 & 46430720.83 & 4.15 \\
\hline 2004 & 45875237.29 & 571564.9851 & 46446802.28 & 1.23 \\
\hline 2010 & 45949509.93 & 518246.0284 & 46467755.96 & 1.11 \\
\hline 2018 & 45850914.58 & 566293.1901 & 46417207.77 & 1.22 \\
\hline
\end{tabular}

Sources:(1958- Historical map, Salem, 1997); (2004- Aerial photography, Kuwait Municipal); (2018, Drone images) and (2010 - 2018, WorldView2- 50cm)

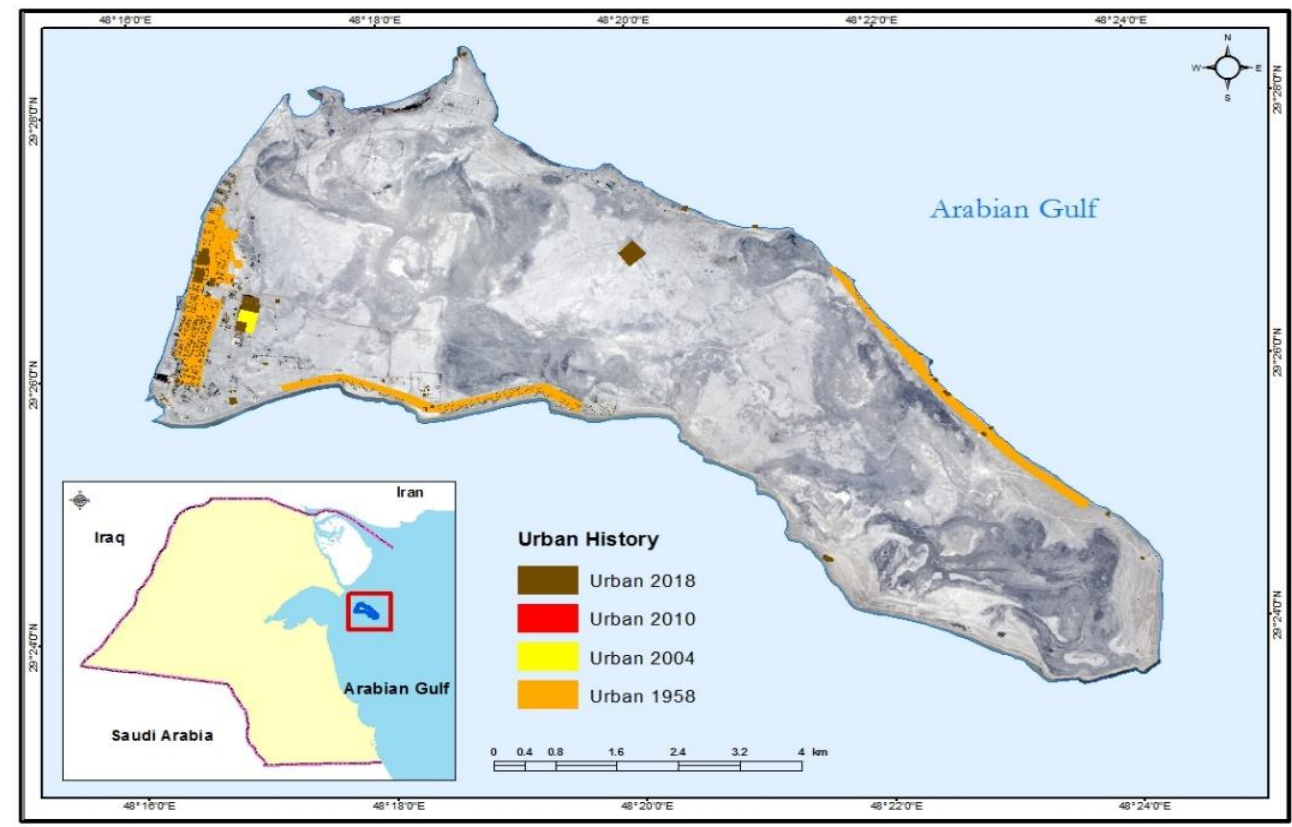

Fig 14. Changes in the urban land use of Failaka Island from 1958 to 2018.

Sources: (1958- Historical map, Salem, 1997); (2004- Aerial photography, Kuwait Municipal); (2018, Drone images) and (2010 - 2018, WorldView2- 50cm)

According to the results (Fig. 14; Table 2), the urban land use did not greatly increase during this period. From 1958 to 2004, the urban land use increased by 16,081 square meters. From 2004 to 2010, the urban land use increased by 20,953 square meters. From 2010 to 2018, the urban land use increased by 50,548 square meters. Based on the types of urban developments in the study area, these changes are reasonable for single-family dwelling structures. The island was mainly used for singlefamily developments until the year 1991, after Kuwait was freed from the Iraqi invasion. After this year, the government moved all residents to the mainland, which changed the structures from singlefamily dwellings to tourist areas. These changes brought on by government policy explain the increase of 50,548 square meters from 2010 to 2018. 
The normalized difference vegetation index ${ }^{3}$ (NDVI) analyses of the Landsat images from 1992 and 2018 were used to determine the changes to vegetation in the study area. Images were collected during the dry season (July 27 -1992, March 29- 2018, 2018 and July 19-2018). The images were classified into two classes: vegetation and non-vegetation. The vegetation class included all land covers that contained chlorophyll, whereas the non-vegetation class included all land covers that did not contain chlorophyll. The map of 1992 shows a high amount of vegetation located near the beach (Fig. 15 a) Where the area of vegetation covers $34.76 \mathrm{~km}^{2}$ (79\% of the island). The island was mostly unoccupied during this period, which might explain its relatively large amount of vegetation. The map of 2018 demonstrates the decrease in the amount of vegetation (Fig. 15 b). Based on the fieldwork and satellite imagery, the non-vegetation land cover includes the Sabkha (Fig. 14 b). This is covered with salt, which was originally covered with water that later evaporated. This land cover increased in the study area as the temperature increased. Therefore, there may be a relationship between the increase in the Sabkha area and the rise in the groundwater level, which has resulted from the recent rise in the sea level. The vegetation area is $28.14 \mathrm{~km} 2$, and this constitutes $63.93 \%$ of the total area of the island.

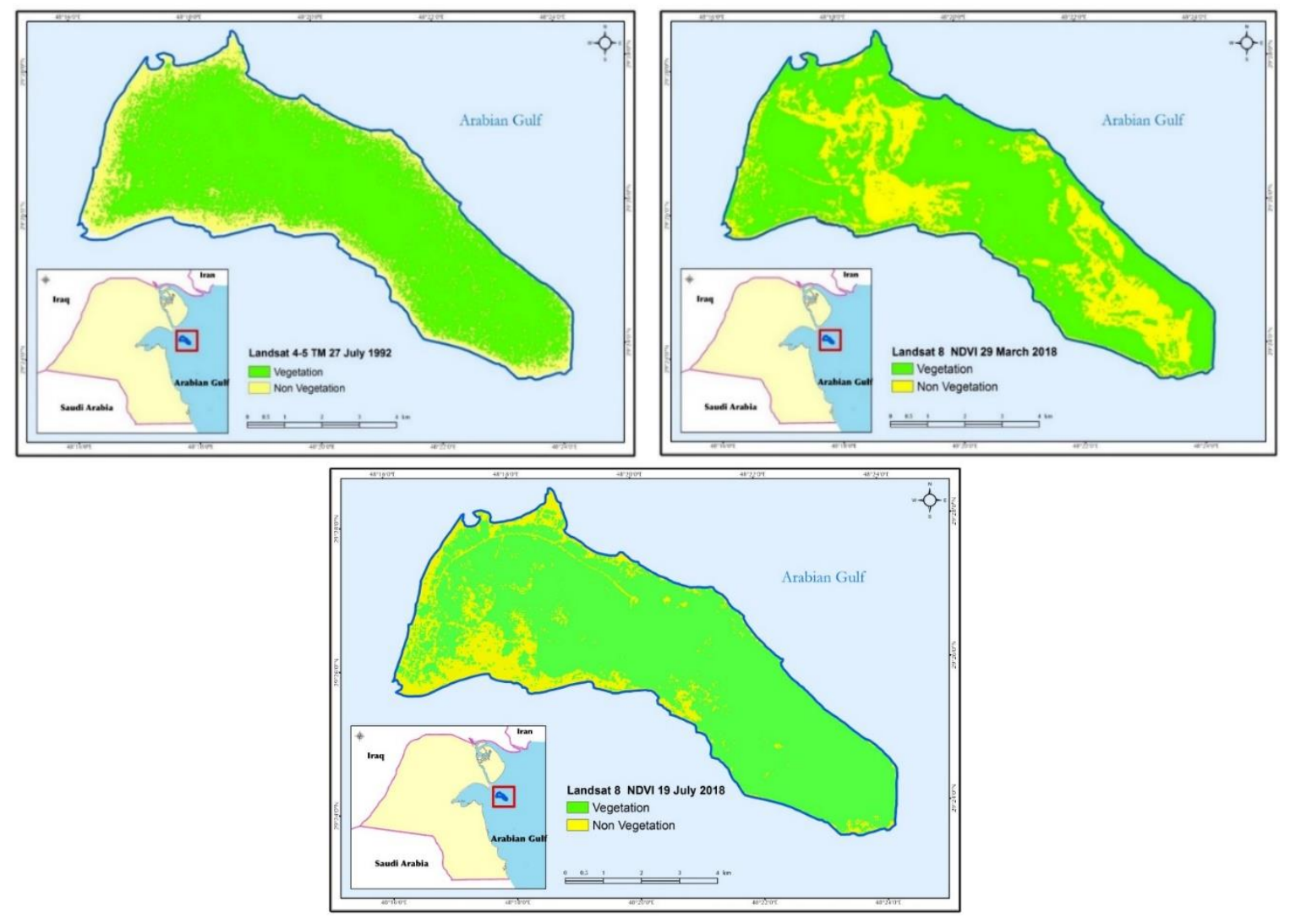

Fig 15. The NDVI analysis result for 1992 and 2018. (Source: Landsat4-5 TM and Landsat 8)

3) Calculated by the famous equation NDVI= NIR-RED/ NIR+RED 


\subsection{The Sea-Level Changes by the End of this Century.}

The government is planning to develop Failaka Island into a tourism hub. There are plans to construct a nature reserve, a residential area, and a tourist marina. Considering the average tide, about one-third of the island will disappear under the sea (Fig. 16 a). Because of the sea-level changes, areas with levels ranging from 0-3 meters may be flooded (Fig. $16 \mathrm{~b}$ ), and some will be exposed to rising groundwater levels, which will increase the Sabkha area. The red area in figure $16 \mathrm{~b}$ represents areas with a range between 1-3 meters. Thus, any study of the Failaka Island environment must take into account the future of the island based on sea level rise scenarios.
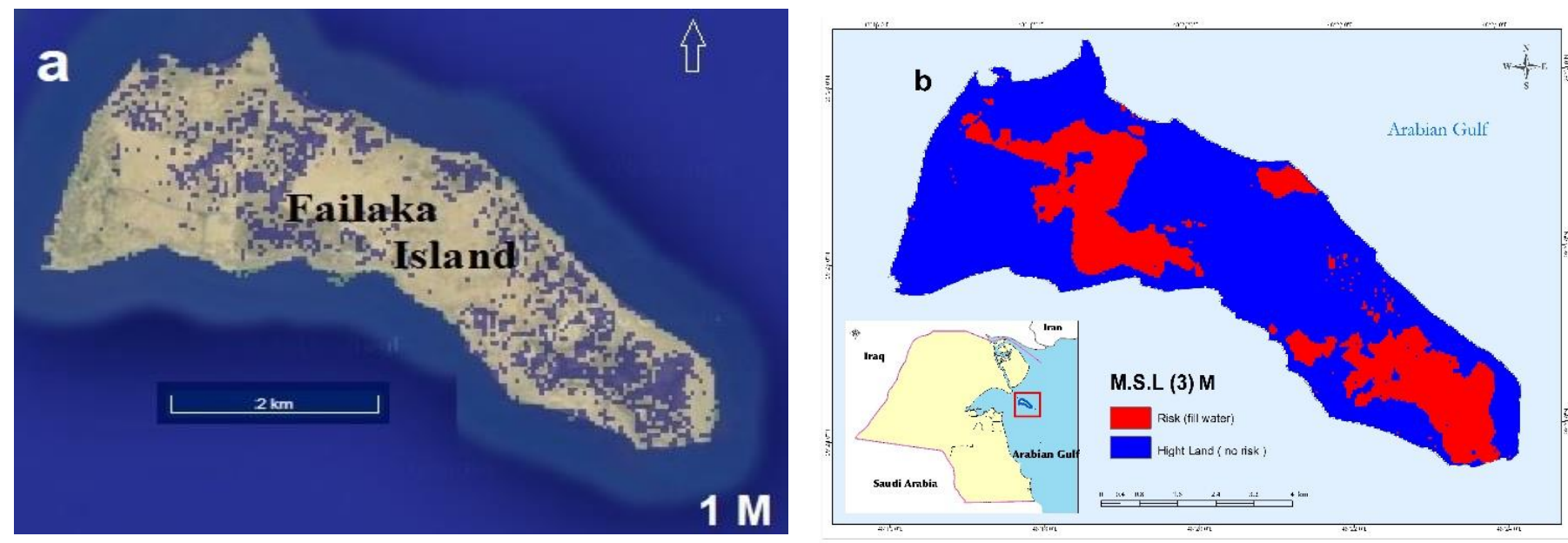

Figure 16. a) The expected submergence of Failaka Island due to sea level rise $1 \mathrm{~m}$ (Source: http://flood.firetree.net). b) The areas at risk of flooding (0-3 m) (source, DEM).

\section{Conclusion}

The study of land-use and land-cover changes allows for specialists and decision-makers to better develop their future plans for regions of great cultural and ecological value. The results of this study trace the history and changing landscape of Failaka Island and contribute to the further development of remote sensing and GIS research within the field of Geoarchaeology. Failaka Island's unique physical and cultural diversity has made it a magnet for Kuwaiti officials, who want it to become a World Heritage Site. A delegation from UNESCO has visited it for this purpose. This study supports the classification of the island as a World Heritage Site.

The area of urban areas decreased from 4.1 in 1958 to 1.2 in 2018. An important change on the island is to increase the area of Sabkha deposits, which is, consist $20.1 \mathrm{~km}^{2}$, and this area constitutes $45.7 \%$ of the total area of the island. After the publication of this study, we will use all the available data to develop an urban plan for the island that will balance sustainable development with ecological preservation. The research results will be useful to the Kuwaiti government, as it will recommend creating buffer zones for all archaeological sites on the island and offer insights into the construction of its infrastructure in the future. 


\section{Acknowledgements}

The authors would like to thank Research sector, Kuwait University, which provided funding for this study (OG01\16). The authors also thank Prof. Andrew Goudie from Oxford University, Prof. Magdy Torab from Damanhour University, Prof. Mahmoud Hassaan from Alexandria University, Dr. Abdallah Zaki from Geneva University, and Dr. Mohamed Nasef from Leeds University, for their valuable comments, which improved the manuscript.

\section{$\underline{\text { References }}$}

- Al-Sarawi, M., Marmoush, Y., Lo, J., and Al-Salem, K. (1996). Coastal Management of Failaka Island. Journal of Environmental Management, 47, 299-310.

- Al-Zaher, A. and M. Aziz. (2004). Optimal Urban Land Use in Failaka Island, Kuwait: Applied Study Using GIS and Remote Sensing. Bulletin of the Egyptian Geographical Society, 77, 105-134.

- Ashkanani, H. (2018). Failaka Island in Postcards. Kuwait: National Council for Culture, Arts, and Letters.

- Ashkanani, H. (2016). Interregional Interaction and Dilmun Power in the Bronze Age: A Characterization Study of Ceramics from Bronze Age sites in Kuwait and its Neighbors. Kuwait: NCCAL.

- $\quad$ Barta, P., Bartík, M., Benediková, L., Ďuriš, J., Pieta, K., Shehab, S. A. H., Štolc, S., and Tirpák, J. (2007). Geophysical Prospecting of the Bronze Age Site Al-Khidr, Failaka Island. Študijné zvesti Archeologického ústavu SAV, 41, 69-73.

- Benediková, L. and Barta, P. (2009). A Bronze Age Settlement at Al-Khidr, Failakah Island, Kuwait. Proceedings of the Seminar for Arabian Studies, 39, 43-56.

- $\quad$ Breeze, P. S., Drake, N. A., Groucutt, H. S., Parton, A., Jennings, R. P., White, T. S., and Crassard, R. (2015). Remote Sensing and GIS Techniques for Reconstructing Arabian Palaeohydrology and Identifying Archaeological Sites. Quaternary International, 382, 98-119.

- $\quad$ Carter, R. A. and Crawford, H. (2003). The Kuwait-British Archaeological Expedition to AsSabiyah: Report on the Fourth Season's Work. Iraq, 65, 77-90.

- $\quad$ Cheruto, M. C., Kauti, M. K., Kisangau, P. D., and Kariuki, P. C. (2016). Assessment of Land Use and Land Cover Change Using GIS and Remote Sensing Techniques: A Case Study of Makueni County, Kenya.

- $\quad$ Dalongeville, R. (1990). Presentation physique de I'ile de Failaka. In Y. Calvet \& J. Salles (Eds.) Failaka: Fouilles Françaises 1986-1988 (pp. 23-40). Lyon: Maison de l'Orient Mediterranean.

- Deroin Jean-Paul, Florian Téreygeol, Pablo Cruz, Ivan Guillot and Jean-Charles Méaudre. (2012). Integrated non-invasive remote-sensing techniques and field survey for the geoarchaeological study of the Sud Lípez mining district, Bolivia, Journal of Geophysics and Engineering, Volume 9, Issue 4, August 2012, Pages S40-S52, https://doi.org/10.1088/17422132/9/4/S40

- $\quad$ Fragkias, M. and Seto, K. C. (2007). Modeling Urban Growth in Data-Sparse Environments: A New Approach. Environment and Planning B: Planning and Design, 34(5), 858-883.

- $\quad$ Goncalves, J. A. and Henriques, R. (2015). UAV photogrammetry for topographic monitoring of coastal areas, ISPRS, Journal of Photogrammetry and Remote Sensing 104, (2015) 101-111. 
- Jesse C, Adam W, Autumn C, Austin H, Kevin F and Elise L. (2017). Archaeological Aerial Thermography in Theory and Practice, Advances in Archaeological Practice, page 1 of 18, Copyright 2017 (C) Society for American Archaeology, DOI:10.1017/aap.2017.23.

- $\quad$ Keay, S. Parcak, S. and Strutt, K. (2014). High Resolution Space and Ground-Based Remote Sensing and Implications for Landscape Archaeology: The Case from Portus, Italy. Journal of Archaeological Science, 52, 277-292.

- $\quad$ KOC (1985). Geology map of Kuwait, Kuwait.

- Kuenzer, C, and Stefan D (2013). Theoretical Background of Thermal Infrared Remote Sensing. In Thermal Infrared Remote Sensing, edited by Claudia Kuenzer and Stefan Dech, pp. 126. Remote Sensing and Digital Image Processing, No. 17. Springer Netherlands, Dordrecht.

- Mannion, A. (2002). Dynamic World: Land-Cover and Land-Use Change. Arnold: Hodder Headline Group.

- $\quad$ Meyer, W. and Turner, B. (1992). Human Population Growth and Global Land-Use/Cover Change. Annual Review of Ecology and Systematics, 23(1), 39-61.

- Mostafa, O. (1988). Failaka Island Regional Study. Kuwait: Kuwait Foundation for the Advancement of Sciences, Kuwait.

- Mukhtar, S. (2016). Land Use Land Cover Change Detection through Remote Sensing Approach in Kano State Nigeria. Pyrex Journal of Geography and Regional Planning, 2(2), 16-28.

- $\quad$ Patitucci, S. and Uggeri, G. (1984). Failaka: Insediamenti Islamici. Ricerche e Scavi nel Kuwait. Rome.

- $\quad$ Picha, F. and Saleh, A. M. (1977). Quaternary sediments in Kuwait. Journal of University of Kuwait (Science) 4.pp. 169-184.

- $\quad$ Pieta, K., Shehab, S. A. H., Benediková, L., Bielich, M., Tirpák, J., and Bartík, M. (2009). Archaeological and Geophysical Survey at Deserted Early Islamic Village Al-Qusur, Failaka Island, State of Kuwait. Ve službách archeologie, 1(9), 29-35.

- Rawat, J. S., and Kumar, M. (2015). Monitoring Land Use/Cover Change Using Remote Sensing and GIS Techniques: A Case Study of Hawalbagh Block, District Almora, Uttarakhand, India. The Egyptian Journal of Remote Sensing and Space Science, 18 (1), 77-84.

- $\quad$ Salem, K. (1997). Failaka Island Historical Map. Kuwait: Kuwait Research and Studies Center, Kuwait.

- $\quad$ Salem, K. (2006). Failaka Island: The Most Famous Kuwaiti islands. Kuwait.

- $\quad$ Satellite imagery: (2004, Aerial photography, Kuwait Municipal); (2010 -2018, WorldView250cm) ; ( Landsat4-5 TM, 1992 and Landsat 8, 2018); (http://flood.firetree.net)

- Shehab, S., Bartík, M., Tirpák, J., Duriš, J., Barta, P., Benediková, L., and Bielich. (2009). Survey and Mapping of Al-Quraniya, Failaka Island, State of Kuwait. Ve službách archeologie, 2(8), 17-22.

- $\quad$ Themistocleous, K., Agapiou, A., Cuca, B., and Hadjimitsis, D. G. (2015). Unmanned Aerial Systems and Spectroscopy for Remote Sensing Applications in Archaeology. International Society for Photogrammetry and Remote Sensing.

- Yoo, C. I. and Oh, T. S. (2016). Beach volume change using UAV photogrammetry Songjung beach, Korea, The International Archives of the Photogrammetry, Remote Sensing and Spatial Information Sciences, Volume XLI-B8, XXIII ISPRS Congress, 12-19 July 2016, Prague, Czech Republic. 


\section{استخدامات الأراضي والغطاء الأرضي بجزيرة فيلكا، دراسة جغرافية وجيوأركيولوجية

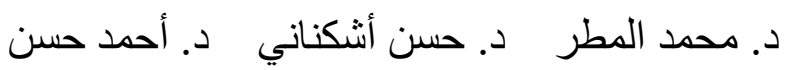

تقع جزيرة فيلكا على بعد حو الي 20 كيلومنرًا من ساحل الكويت، تضم الجزيرة مو اقع أثرية يعود ناريخها إلى العصور :

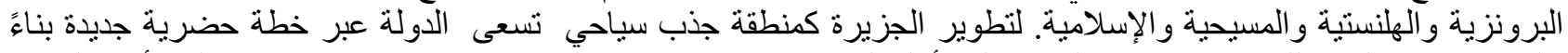

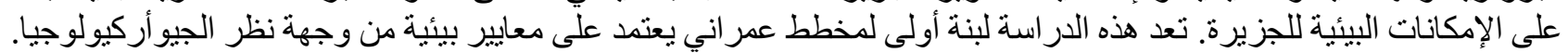

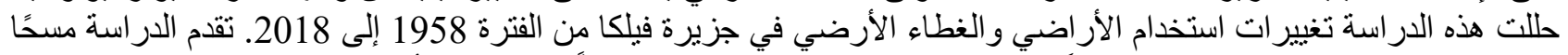

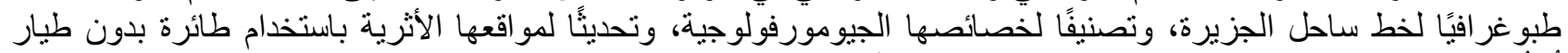

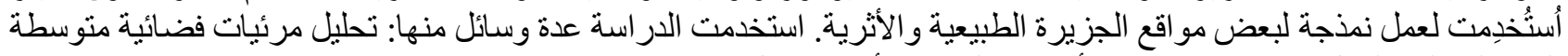

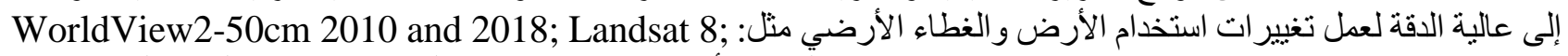
aerial photography and Drone images

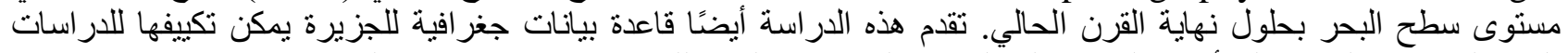

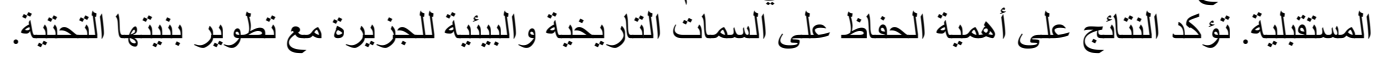

الكلمات المفتاحية: 


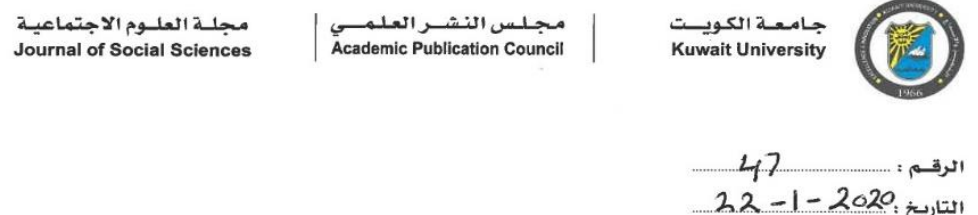

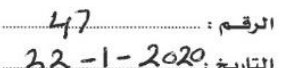

Dr.Muhammad Almatar

Dr. Hasan Ashkanani

Dr. Ahmed Hassan

With reference to your paper entitled :

“ Investigating Land-use and Land- Cover changes of Failaka Island : Astudy in Geography and Geoarchaeology “

I am pleased to inform you that your paper has been Accepted for publication in the near future.

Dr. Maha M. Al Sejari

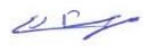

Editor-in-Chief

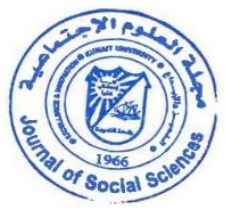

Journal of the Social Sciences, ISSN: 0253-1097

http://pubcouncil.kuniv.edu.kw/jss/home.aspx?id=1\&Root=yes
Journal of the Social

Sciences

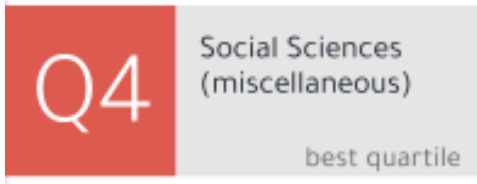

SJR 2019

0.11

powered by scimagojr.com 